\title{
THE PUBLIC INTEREST IN LABOR DISPUTE SETTLEMENT
}

\author{
JeSSE FreIdiN*
}

It is difficult to conceive how, in the long run, the public interest in the settlement of labor disputes can be successfully distinguished from the common interests of labor and management. The welfare of the nation is dependent on the success with which the worker and the employer. fulfill their respective functions. No policy, regardless of how it is labeled, can effectively serve the public interest which does not serve the interests of democratic trade unionism on the one hand and the system of private enterprise on the other. Nor can a policy succeed that does not contain within itself respect for the economic and personal liberties of all citizens, regardless of the side of the table at which they sit. Consequently, when, in the language of the policy makers, we speak of the "public interest," we have-under discussion not a system of devices designed to protect one autonomous group of the population from attack by two others, equally independent, but a program that must be calculated to promote the interests of both workers and employers, for to one of these categories most citizens belong.

And so this paper will not discuss a program designed to immunize nonparticipants against the consequences of labor disputes. Instead, the discussion will be based on the premise that the public interest will best be served by the formulation and acceptance of a program devised to serve the common aspirations of industry and labor to promote industrial peace without sacrificing basic concepts of economic and personal liberty.

\section{I}

I doubt that during the eighteen months following V-J Day there occurred a single major labor dispute that did not end up with editorial demands for amendment of the National Labor Relations Act. The authors of these demands appear to have accepted what seems to be a misconception of that statute. They have assumed some necessary casual relation between the Act's provisions and the inability of a particular company and union to agree on the terms of a collective bargaining contract. ${ }^{1}$ There is, of course, no such immediate or direct relationship. The National Labor Relations Act was neither conceived nor enacted, nor could it

- Litt.B. I930, Rutgers University; LL.B. 1933, Harvard University. Member of New York Bar; formerly General Counsel, Public Member, National War Labor Board.

${ }^{1}$ In this regard a recent Gallup poll has revealed some very provocative results. In response to the question, "What is your understanding of what the Wagner Labor Act provides-or is supposed to do?", $19 \%$ of those interviewed indicated "that they have at least a general idea of what the Act is, while $12 \%$ gave a totally incorrect answer, and $69 \%$ said they simply do not know what the Wagner Act in Washington Post, Jan. 10, 1947, p. 9, col. 5. 
have been administered, as a means of resolving disputes over basic contract conditions between organized workers, acting through their duly designated bargaining representative, and their employer. Probably the most explicit negation of any such purpose is to be found in the 935 report of the Senate Committee on Education and Labor, to whom the pending measure had been referred:

Prudence forbids any attempt by the government to remove all the causes of labor disputes. Disputes about wages, hours of work and other working conditions should continue to be resolved by the play of competitive forces, so far as the provisions of codes of fair competion are not controlling. 2

Congressional ambitions at the time were relatively modest. To give "definite legal status to the procedure of collective bargaining" was the limited purpose of the enactment. ${ }^{3}$ The record of industrial strife in manufacturing industries during the period preceding 1935, in contrast to the relative peace that had prevailed in the railroad industry consequent upon legislation ${ }^{4}$ that had consistently recognized and sought to protect the right of railroad workers to organize and bargain collectively, persuaded Congress that it was feasible-to eliminate at least that one issue from the area of contention.

The Wagner Act therefore addresed itself only to the issue of how, peacefully, the parties were to be brought up to the collective bargaining table. From there they were on their own, their disputes to be resolved by the "play of competitive forces."

Success in accomplishing the avowed purpose of the Act, if honest recognition is given to its limited purpose, has been marked, though it was by no means immediate. The best indication of how gradual has been acceptance of the orderly procedures established by the Act to resolve questions of organization and representation is to be found in the tenth annual report of the National Labor Relations Board, which reflects a consistent rise in the ratio of representation cases to unfair labor practice cases. In 1937, for example, unfair labor practices comprised 7I per cent of all cases filed with the Board, as against 29 per cent representation cases. In I94I the trend toward representation cases started. They constituted $47.4 \mathrm{per}$ cent of the cases filed. In 1945 this figure had jumped to 75 per cent, in sharp contrast to the 19 per cent proportion of $1936 .^{5}$

\section{II}

We would consequently be mistaken were we to attribute to the Wagner Act exclusive or major responsibility for the strikes of 1945 and 1946 . In fact, it is note-

${ }^{2}$ SEN. ReP. No. 573, 74th Cong., 1st Sess. 2 (1935).

Congress had before it at the time data establishing the fact that $74 \%$ of all the disputes that had come before the then existing National Labor Relations Board during the second half of 1934 were over the employer's refusal to recognize the employees' right to bargain collectively through their own repreentatives.

"Beginning with the Act of Oct. I, 1888 (25 STAT. 50I) and culminating in the I934 amendmeanus to the Railway Labor Act ( 48 StAT. 1185). See 45 U. S. C. 1151 et seq. (1940).

10 N. I. R. B. ANN. Rep. 2, 3 (1946). 
worthy that not one of the major disturbances during those years involved the once popular issue of organization and the right to bargain collectively. The truth of this conclusion is demonstrated in a report of the Bureau of Labor Statistics on I945 work stoppages. ${ }^{8}$ Not a single major dispute in 1945 involved the issue of union recognition with respect to production workers. Only two disputes involved the issue in any form, and both of those related to the still unsettled question of supervisory employees. ${ }^{6 *}$ Less than 4 per cent of the time lost through strikes, fewer than 14 per cent of the workers involved in strikes, and only 12 per cent of all disputes included controversy over the question of union recognition. To be contrasted with these facts is the data covering the years $1935-1942$, when more than 50 per cent of all labor disputes were over that single question.

There is, then, no obvious correlation between the present form of the Wagner Act and the recent strikes in major industries. It is possible to attribute responsibility to the Act only if we are prepared to say that Congress misplaced its confidence when, in adopting the Act, it contemplated that differences over wages, hours and working conditions would be resolved through collective bargaining. Sober reflection as to the sources and causes of the industrial strife since V-J Day, the large proportion of disputes peacefully resolved through negotiation, and the relative inexperience in collective bargaining of the parties to strike cases will indicate that any such conclusion would be premature.

In the first place, attention has been too readily diverted from the normal to the exceptional. Far too little attention has been focused on the successes rather than the failures of collective bargaining. If one were to base a judgment only on news reports of labor relations one would need to conclude that strike is the rule and peaceful agreement the rare exception. The truth, however, is quite the reverse. The dramatic strike rather than the sober agreement may compel the attention of news reporters, but in a deliberate and careful appraisal of national labor policy the success of the process of free and peaceful persuasion must be given honest weight. The fact is that more than 80 per cent of all organized workers have resolved new contract conditions without strikes or other interruptions of production since V-J Day. ${ }^{7} \quad$ Nor, in determining whether the character and extent of the disputes that resulted in strikes during $1945-46$ are typical of labor relations in normal circumstances, is it possible to overlook the unique problems that.had to be faced. Industry and labor had to grapple with wholly novel issues of the severest difficulty, agreement had to be sought in an atmosphere charged with great tension, and in

- Work Sloppages Caused by Labor-Management Disputes in 1945, B. L. S. Bull. No. 878 (U. S. Dept. Labor 1946). "Major dispute" here means one involving 10,000 or more workers.

- The question whether foremen as a class are entiled to the rights of self-organization, collective bargaining, and other concerted activities assured to employecs generally by the National Labor Relations Act was not finally decided until Packard Motor Car Co. v. NLRB, 67 S. Ct. 789 (March 10, 1947). This decision also upheld the power of the board to treat foremen 252 class as an "appropriate bargaining unit." [Ed.]

Ibid. 
many situations these highly challenging problems were approached by companies and unions unskilled in dealing with each other.

Prior to I935 union organization in mass-production industries was relatively unknown. Organized labor consisted of approximately three million employees concentrated in the mining, construction, transportation, maritime and needle-trades industries. In automobiles, steel, electric equipment, meatpacking, textiles, and other large-scale manufacturing processes, aggressive, independent unions simply did not exist. Nor did they spring full grown from the passage in 1935 of the Wagner Act. Until 1937, when the constitutionality of the Act was finally accepted, there was not much more than a pretense at collective bargaining. Even organizational efforts remained more or less moribund. In 1937 the battle of organization began, with the National Labor Relations Board and the courts for some time thereafter busily occupied in meeting both bona fide and mala fide efforts to avoid the compulsions of the Act. From that time until our entry into the war the major efforts of the unions in the mass-production industries were concentrated more on achieving a representative status in the mills and factories of the rountry than on trying to negotiate collective-bargaining agreements. This is reflected in the fact that from 1935 to 1942 the issue of union recognition alone accounted for more than half of all labor disputes in the nation.

From 194I until the end of the war the restrictions of a wartime economy, the imperative needs of uninterrupted production and economic stabilization, and a nearly completely regimented society almost eliminated the opportunity for free collective bargaining. There was little opportunity for labor and industry to gain during the war years any experience in devising joint solutions to mutual problems. The wartime readiness of the government to make decisions deprived both sides of an educative experience. The war did, however, furnish the source of the perplexing problems that had to be faced in the postwar adjustment. The fight over price control had transformed many wage disputes between an employer and a union into price disputes between an industry and the government. At the war's end workers suffered losses in income resulting from the shortened work week, downgrading of employees, shifts of great groups of workers from high- to low-paying industries, the stricter administration of incentive systems; and then came the constant and sharp rise in living costs. For the worker the economic impact of these developments was unquestionably intensified by the emotional release from wartime wage controls. Nor were the employers' problems a great deal easier. In '1945, for the first time in five or six years, cost reassumed its traditional importance. The guaranteed wartime market, ready to consume and pay any price for whatever could be produced, was about to be replaced by a competitive economy in which a producer could without much difficulty find himself priced out of the market.

It surely could not have come as a shocking surprise to those who were tamiliar 
with the sudden growth and development of organization in the mass-production industries that not all companies and unions were able to find their own solutions to all problems. The really gratifying fact is that so many did. There are, however, two noteworthy factors of which not sufficiently frequent mention has been made. One is that violence and lawbreaking in strike conduct was largely nonexistent. Each party recognized and respected the other's right to disagree. In itself this is a development of significance when considered in the sequence of the long and bitter struggle to establish collective bargaining as one of the principles of our democratic society. The other notable fact is the extent of agreement that prevailed in industries in which collective bargaining had attained a measure of maturity-agreement reached without strike or lockout, in the face of the most trying of circumstances, and covering some 80 per cent of all workers who were members of labor unions. Parenthetically, it is of interest to note that in the strikes which did occur the AFL and CIO were about equally involved. That is to say, unions affiliated with the CIO were involved in 40 per cent of the stoppages that occurred in 1945, AFL unions were connected with 37 per cent, and unions affiliated with neither of the two major labor organizations were involved in about 17 per cent. $^{8}$

Three conclusions of ultimate importance emerge from these facts:

(I) The National Labor Relations Act has succeeded in its limited immediate purpose of removing the issue of union recognition from the area of labor-management controversy.

(2) In the peaceful settlement of the vast majority of labor disputes through collective bargaining, even in the difficult immediate postwar year, the Act has also achieved a substantial measure of indirect success.

(3) We have had only a limited collective-bargaining experience in the massproduction industries, where the preponderant majority of workers who participated in strikes are employed, and even that limited experience has been chiefly confined to unique economic circumstances. Where, on the other hand, the parties entered into their I945 negotiations with a mature experience in dealing with each other, strikes were relatively unknown. ${ }^{9}$

\section{III}

Honest and dispassionate consideration of these conclusions ought to remind us of the danger of throwing out the baby with the bath water. For while their acceptance does not preclude efforts to review and improve the national labor policy, there is a real threat that in the heat of present public concern an intemperate or hastily. conceived program will be formulated that will have the effect of permanently injuring the processes of free collective bargaining.

\footnotetext{
Id. at 22.

- For example, in the apparel industry only $1.7 \%$, in the printing industry $3.7 \%$, and in the construetion industry $5.8 \%$ of all the workers employed were involved in strikes. In all three industries union organization is extensive. The comparable figure for all manufacturing is $19.6 \%$. (Id. Table 4 ).
} 
It must be realized that the present unbalance of labor's power is not so much due to the inherent nature or strength of labor unions as to the strength of the economic forces now at work, forces that are characteristic of an economy of scarcitylabor shortages and the need for maximized production. The great danger is a refusal to recognize this fact, and a willingness instead to assume that the extent of the power now possessed by the organized worker and the pervasive effects of its exercise are necessary elements of a strong labor movement operating in a normal economy rather than the result of a set of exceptional economic circumstances. Our entire governmental effort is being directed toward a return to a normal economy. It would be illogical to base a reappraisal of our labor policy on the premise, so wholly at odds with this overriding governmental aim, that the emergent forces of the immediate postwar period, predominantly responsible for recent labor unrest, will continue. The objective of our reappraisal must therefore be to buttress and support the processes of free collective bargaining, on the assumption that we are headed for a normal economy, and to eschew ill-considered compulsory devices which, if applied at the beginning to wages, must eventually be applied also to prices, profits and production. Free enterprise will not long be maintained once we have abandoned free collective bargaining.

It is in this light that the public interest requires that proposals to change or implement our national labor policy be considered. For it has become apparent to the thoughful person that many of the proposals put forward ostensibly for the purpose of encouraging free collective bargaining will have just the opposite effect. Typical of those proffered panaceas are those that insist that the government must be ready to intervene as decision-maker in major disputes when the parties are unable to agree. Fact-finding in a variety of forms and compulsory arbitration are most freqently offered as the machinery by which government is to execute this function.

But any device that holds out the government as an available instrument for fixing wages, hours, and other conditions of employment impairs, to the extent of its availability, the process of collective bargaining. For in one party or the other to many major disputes the hope will persist that more can be gained by appealing to the government than by agreement; and the vicious circle is that, as the process of agreement-making is thus weakened, the need for government intervention will grow more critcial. Until the government makes as plain as the English language permits that it is out of the decision-making business, there must be included in the list of causes of strikes the desire to compel government intervention.

It is, moreover, not only in the immediate case that efforts to reach agreement are prejudiced by the readiness of a government agency to make the decision. Others in the same or related industries, or the same or adjacent areas, find themselves bound by a decision made in a case to which they were not parties. Regardless of protestations to the contrary, the undeniable fact is that from one or two major cases 
in which the decision (regardless of whether it is labeled a "recommendation" or "finding") has been made by the government there emerges the equivalent of a national policy (e.g., the $I 81 / 2$-cent pattern of $1945-46$ ) from which deviation in other cases is extremely difficult if not wholly impossible, regardless of differences in wage history, cost considerations, competitive outlook, nature of operation, product, or even industry. The entire institution of collective bargaining is thus progressively weakened by government's assumption of the role of decision-maker.

Nor will the compulsive character of official activities be lessened by labeling the results as "findings" or "recommendations." Professions of the freedom of the parties to reject or accept the findings or recommendations are simply double-talk. The government's prestige, the force of public opinion demand obedience; indeed, the avowed purpose of the procedure is to induce acceptance through the operation of these forces.

Even in regard to limited categories of industries such as public utilities, to which proposals for government intervention might be confined, the same considerations are valid. It is, moreover, quite obvious that our integrated economy no longer permits easy definition of "industries affected with a public interest," particularly when what we are trying to define is a class of services the interruption of which entails significant inconveniences for the community. As introduced in the House and Senate, for example, the proposal for the creation of fact-finding boards ${ }^{10}$ covered unsettled disputes certified by the Secretary of Labor as affecting or threatening to affect "the national public interest and ... interstate and foreign commerce." Could the steel, meatpacking, transportation, maritime, or coal industries be omitted from such a broad definition? Could, in fact, any dispute involving several thousand workers be left out, whether it occurred in the automobile or the textile industry, or any of the other highly organized, mass-production industries? The War Labor Board's wartime experience reveals the difficulty of drawing a reliable distinction between disputes that threaten the public interest and those that do not. The criterion of the Board's jurisdiction was an interference, actual or threatened, with the war effort, evidenced by certification of the Secretary of Labor. It was soon found that strikes or potential strikes could not be isolated nor confined within geographical boundaries, nor could their contagious effects on workers not immediately involved be precisely foretold. And it was not easy to explain to workers that their dispute was not serious enough to warrant government's formal attention. The risk was that such a statement would be accepted as a challenge to aggravate the nature and threatening quality of the dispute. As a consequence, all disputes were held to $:$ be subject to the Secretary's certification because, with infrequent exceptions, each contained the seeds of widespread and contagious industrial conflict. It is doubtful that a peacetime agency could successfully resist the adoption of a similar practice.

Experience under the Railway Labor Act furnishes a very doubtful precedent ${ }^{20}$ H. R. 4908, 79th Cong., Ist Sess. (1945). 
for broad extension of government intervention. As finally amended in 1934 it was, in the first place, the result of long experience with and constant change of earlier enactments which had sought unsuccessfully to deal with labor disputes in the railroad industry. The amendment of 1934 marked the culmination of fifty years of legislative experiment in this field of mediation. Under the Act of 1888, the Erdman Act of 1898 , the Newlands Act of 1913, the Adamson Act of 1916, government possession during the first World War, and the Transportation Act of 1920 the results were dismal. ${ }^{11}$ Even as radically altered in 1926 and finally amended in 1934 the procedure has not been foolproof. Witness the railroad strike of 1946 . But aside from this half century of actual experience, the fact of critical importance is that, as adopted in 1926 , the Railway Labor Act was the result of joint agreement between the unions and the carriers. If we are to be influenced by any precedent surely it should be by this fact of voluntarism.

In contrast is the unanimity of the great organizations representing labor and industry in vigorously opposing the application of the Railway Labor Act's factfinding or emergency-board techniques to the rest of industry. ${ }^{12}$

IV

There are, however, steps the government can take, designed to aid parties to a labor dispute to reach their own agreement, but uncoercive in character. Two broad categories of activities can be envisaged. The first would include expansion and improvement of active government participation, limited, however, to mediation and conciliation; the second would consist of collating and making available information pertinent to many of the pressing issues in over-all management-labor relations as well as in particular disputes, and of furnishing personnel trained and expert in the technical problems that affect worker and employer.

As to the first, the government's mediation techniques and facilities have not kept pace with the growth in size and complexity of the problems of industrial relations. Few, if any, changes have been made in the organization and extent of federal conciliation facilities since the service was first established in 1920 . Recent efforts of the Director of the Conciliation Service are very encouraging, however. He has, for example, established three separate bodies-the first an over-all advisory committee; the second a group of labor and management representatives of a particular industry, public utilities; and the third a group of labor-management representatives of a particular area, the Middle Atlantic states. This is a significant beginning of an effort to achieve labor peace on the basis of voluntarism. It is important, too, because it recognizes that in some situations successful labor-management relations can

${ }^{21} 25$ Stat. 501 (1888); 30 STAT. 424 (1898); 38 Stat. 103 (1913). 45 U S. C. \$\$101-125 (1940); 39 Stat. 721 (1916), 45 U. S. C. $\$ \$ 65,66$ (I940); 4I Stat. 456 (1920).

23 See, for example, the recommendations of the U. S. Conciliation Service's Labor-Management Advisory Committee, N. Y. Times, Dec. I7, 1946, p. I, col. 2. Sce also N. Y. Times, Jan. 6, 1947. p. 8, col. $\mathrm{I}$. 
be encouraged if the problem is approached on an industry basis, while in others a community or area basis is needed. And it may well be, although this is not clear, that both specialized groups are to operate within the broad policies established by the advisory committee.

The expansion of such experiments as these will far more effectively promote industrial peace within the framework of a free economy than will any program based on coercion, regardless of what it is called. Labor disputes do not fall into logical patterns. Each is different from the others in issues, in character of past relationships, in personalities involved, in technology, in wage-price ratios, in industry and area repercussions. Experience has revealed that, because of such differences, flexibility in mediation and conciliation methods is of fundamental importance. A tripartite board of mediation will function successfully in some cases, a single mediator in others; area or community representatives will be effective in certain types of situations while in others designees of the industry in which the dispute has arisen will be able to exercise greater persuasive powers; in still other cases efforts of representatives of the industry immediately involved will be resented because of reluctance to disclose to competitors information of a confidential nature, while efforts of representatives of a related or wholly different industry will be welcomed. In some cities (New York and Toledo, Ohio, for example), local mediation facilities will possess advantages that state or federal agencies do not possess. Frequently different techniques will be required to avoid a strike than to settle one that has already occurred.

An expanded conciliation service will not achieve maximum efficiency if limited to a rigid or a single procedure. There must be in the hands of the responsible administrator authority to adapt mediation techniques to the characteristics of individual situations. The defect of many of the proposals that have been made for the establishment of super-mediation bodies is that they fail to take sufficient account of this need for adaptability, ${ }^{13}$ and that they do not make plain that the government's aid will be limited to mediation and conciliation and will stop short of making official decisions or official recommendations in such form as to be tantamount to a dictated settlement. It is doubtful, moreover, whether any net gain will result from superimposing on the Conciliation Service a mediation agency with superior status. The probability is simply that a lot of cases that might have been settled by conciliation would be held out for the attention of the super-body in the hope that some advantage would accrue to one side or the other through the lapse of time necessary to get from conciliation to the super-agency or through the force of some other circumstance. It is fairly common knowledge that as long as some higher forum or official is available, the last ounce of effort toward compromise will not be made at the lower level but will be withheld until the higher forum is reached and its efforts invoked.

\footnotetext{
12 The Ball-Burton-Hatch bill, for example, would have made it mandatory for the federal conciliation agencies to intervene in important disputes. As the bill is now worded there would be no opportunity to consider whether state or local mediation facilities could be utilized more effectively.
} 
In any attempt to improve our mediation services the organization of government mediation in Sweden and its record of substantial achievement is worth careful study. ${ }^{14}$ The country has been divided into seven districts with a mediator for each district. The mediator is given notice of the inception of negotiations which, by law, must commence not later than three months prior to the expiration of the current contract. He is thus qualified to enter the situation formally, should that become necessary, by his familiarity with local circumstances bearing on the issues, with the personalities representing the two sides, and with the particulars of the dispute. As a consequence his competence and impartiality evoke the confidence of both sides. The law establishing his office requires him carefully to report each case in which he participates. His reports are printed each year in summary form by the Ministry of Social Affairs, thus aiding in the establishment of responsibility of all participants in the mediation process, including the mediator himself, and building up case records to which other parties and mediators may have access. While the mediator has authority to require the parties to attend his meetings, all proposals for compulsory arbitration of the terms of settlement have been cansistently rejected. This latter fact is true also of the procedures in Denmark and Norway.

It is not suggested that the patterns established in the Scandinavian countries, even though they have operated with marked success, would be adequate in this country, where our economy and all the components of industrial relations are vaster and infinitely more complex. But the experience of those countries, since the aspirations of workers and employers in any free economy are substantially similar, should surely be consulted before radical changes which would substitute coercion for freedom are enthusiastically embraced. There seems, for example, to be great merit in establishing mediation districts, either by geographical or industry boundaries (utilizing existing state and local mediation facilities); in vesting the officials of such districts with sufficient discretion so that the various techniques described above can be applied to the needs of different situations; in providing for ample time (say, three months) for negotiations for new agreements; in keeping the appropriate mediation official apprised of the beginning and development of bargaining; and in maintaining case-history records as guides in other situations. .

Here, it is submitted, is a fertile subject for study by the Labor-Management Advisory Committee of the United States Conciliation Service. It is not clear whether this group is to be an organized, continuing body with recognized status, but consideration might well be given to granting it Congressional recognition and authorizing it to formulate, through agreement of its labor-management representatives, basic general policies and operating devices. Experience during World Wars I and II has demonstrated the fruitfulness of such a continuing organization. It could be of inestimable help, not only in settling major disputes through its own efforts, but also in proposing procedures for the settlement of other disputes through

24 See Paul H. Norgren, the Swedish Collective Bargainixg SysteM (I94I), esp. c. XI. 
local or district or industry representatives. Through liaison maintained with the labor committees of the House and Senate, with the Secretaries of Labor and Commerce, and with other administrative officials concerned with labor policy, it could also aid in legislative and administrative functions dealing with the maintenance of industrial peace.

Such a group would possess the advantages of voluntarism, continuity of experience and policy, and adaptability. It would encourage agreement and stimulate joint effort by representatives of industry and labor in the solution of single disputes and in the formulation of broad policies.

\section{V}

There is a complementing service that might also be of assistance to industry and labor in the making of their own agreements. As collective-bargaining relationships acquire maturity the setting of wages and the adoption and modification of working conditions become less and less matters of chance, and more and more matters of sophisticated and rational discussion in which the possession of precise information, accurate data, and intelligent understanding become of critical importance.

The invaluable service rendered by the Bureau of Labor Statistics in compiling cost-of-living and wage-and-hour data could be supplemented by the gathering of information on other subjects that have assumed major importance in industrial relations. The 1945 blow-up over the subsequently disavowed Wallace report ${ }^{15}$ and the current fracas over the so-called Nathan report ${ }^{16}$ indicate, for example, the increasing significance in the settlement of labor disputes of wage-cost-price relationships. There is good reason to suppose that a clearer understanding of this subject than presently available reports permit would be of significant aid to both sides in resolving wage disputes. ${ }^{17}$ The study now being made under government auspices of the feasibility and limitations of annual wage plans furnishes sound precedent for a similar study of wage and price relationships. Nothing helps so much in promoting co-operative efforts as does comprehension based on impartial sources of information.

Questions of labor productivity and unit labor cost are similarly obscured by the paucity of reliable information, and, so obscured, have been productive of much unnecessary disagreement. A project is now under way ${ }^{18}$ to measure man-hours of labor required per unit of production cost, volume of production, and labor costs per unit of production. So far as news reports reveal, however, it ic uncertain

${ }^{10}$ N. Y. Times, Nov. 2, 1945, p. I, col. 6

${ }^{10}$ Routrt R. Nathan and Oscar Goss, A National. Wage Policy for ig47 (1946).

${ }^{27}$ On December 12, 1946, the Federal Trade Commission released some figures on the relation, by industry, of labor cost to dollar sales. The ratio varied from 3.2 cents per dollar of sales in cigargttes and tobacco products to 33.2 cents in hat and cap manufacturing. The figures, however, were for 1939 and did not purport to be complete. N. Y. Times, Dec. 13, I946.

${ }^{18}$ Productivity Changes Since 1939 (1946) 63 Mo. LaB. Rev. 893. 
whether labor is to have representation on the committee responsible for making the survey or on whatever body is to have responsibility for interpreting the accumulated data. Nor is it apparent whether this is to be on an industry or craft basis nor how extensive its coverage is to be. If the results of this effort are to realize its fullest potential utility it is important that the project be beyond any challenge as to bias or coverage.

Related to questions of increased productivity and reduced unit labor cost are problems of technological improvement and worker displacement. In the great majority of instances worker resistance to the introduction of labor-saving devices is a natural reaction of fear of loss of the opportunity to earn rather than arbitrariness, meanness of spirit, or reactionary desire to retard mechanical progress. But since in the ultimate analysis it is economically possible to increase respective shares of the production pie only by baking a larger pie, it is important that the resistance be overcome; not, however, through such abortive devices as the Lea Act, but through understanding and intelligent application of the history of technological advance, the essence of which is that more and larger earnings opportunities are created than are lost by improving technology. Here, too, the government, as the source of impartial analysis and information, can render useful service by a careful study of the effects of technological innovations on earnings opportunities and by readiness and ability in a particular situation to explore with company and union the probable consequences of a contemplated machine innovation, change of operations, or material, and methods by which the economic impact on the workers can be avoided or minimized.

There are unquestionably many other directions in which the government could exert fruitful effort in accumulating and making widely available information and data to be utilized in individual disputes or as the basis for the formulation of national policy. The success and mechanics of profit-sharing plans that might make possible more generous worker participation during years of unusually profitable operations, without raising the basic wage structure to a level which in ordinary or lean years would constitute a competitive embarrassment to the employer, is certainly worth more official study than it has yet received. Various kinds of incentive systems, their methods of operation, their effects on production and earnings, and their adaptability to operations and industries in which their introduction has been opposed, are another rich field of inquiry. Careful job analysis and evaluation and the establishment of effective job differentials can do much to eliminate in-plant dissatisfaction.

It is firmly believed that, if the government were able to make available not only information on these matters, but also persons trained and expert in these fields who could be invited by disputing parties to aid them in the solution of particular problems, the science of collective bargaining and its potential accomplishments would be vastly enchanced. 
VI

The preceding discussion has dealt only with those aspects of government policy that might encourage free and private agreement-making. But since the ultimate result of that process is an agreement, the success of the entire policy must turn on the honest adherence by both sides to the obligations and responsibilities explicit in the agreement and implicit in the relationship. There cannot, in other words, any longer persist any doubt regarding the enforceability of these agreements or the availability of sanctions for their breach.

There is much misunderstanding as to the legal status of collective-bargaining agreements. Contrary to popular impression they are enforceable, and have been enforced by the courts in suits by employers, by unions and by employees. ${ }^{19} \mathrm{~A}$ good deal of the confusion results from the failure of the courts to define clearly the nature of the rights being enforced or the legal character of the contract. Some courts, for example, have adopted the theory that such agreements establish a usage or custom which, by implication or express agreement, becomes a part of the individual employment contract, ${ }^{20}$ and that it is only this individual contract that is being enforced. Such a theory is obviously defective in ignoring the relationship between the union and the employer. ${ }^{21}$ In other courts suits have been maintained on the ground that the contract was made by the union as agent for the employees; ${ }^{22}$ and in others the rationale has been that the contract is enforceable like any third party beneficiary agreement. ${ }^{23}$ It would be obviously desirable, because of the importance of the interests not only of the immediate parties to the contract but of the entire community in insuring the stability that inheres in firm labor contracts, for the courts to

20 "That any individual can obtain redress for the breach of a collective bargaining agreement is 'no longer' an open question. I say 'no longer' because earlier courts accompanied their, shall we say rigid attitude toward the working man or woman, generally, by a specific hostility to his rights under 2 collective labor agreement. But modern judges, despite the divergence of theories adopted, will enforce these agreements at the instance of employer, employee or union. Nor will specific enforcement be barred by the ancient and now considerably weakened 'slavery' doctrine. Whatever the effect given to individual employment contracts, collective agreements are held to be in a special category. So where moneg damages are inadequate equity will enforce their terms." Clark, J. dissenting in N. L. R. B. v. Newark Morning Ledger Co., 120 FED. 2d 262 (C. C. A. 3d I94I), cert. denied 3I4 U. S. 693 (194I).

"A union, although a voluntary unincorporated association, is legally responsible for its acts in much the same way that an individual, a partnership or a corporation is responsible. If a union, through its constituted agents, commits a wrong or is guilty of violence or of illegal oppression, the union, and not merely the individuals who are the direct instruments of the wrong, can be enjoined or made liable for damages to the same extent that the union could be if it were incorporated; and the funds belonging to the unincorporated union can be reached to satisfy any damages which might be recovered for the wrong done." Brandeis, Business-A Profession (I933) 93.

${ }^{20}$ System Federation v. Louisiana \& A. Ry., I I9 FED. 2d 509 (C.C.A. 5th I94I); Hudson v. Cincinnati, N. O. \& T. P. Ry., 152 Ky. 711,154 S. W. 47 (1913). The major defect of this theory is that it leaves unresolved the question of suit between the union and the employer.

${ }^{21}$ Nederlandsch Amer. S. M. v. Stevedore's \& Longshoremen's Ben. Soc., 265 Fed. 397 (E.D. La, I920); Schlesinger v. Quinto, 201 App. Div. 487, 194 N. Y. Supp. 401 (Ist Dept. I922).

$=2$ Barnes \& Co. v. Berry, I69 Fed. 225 (C. A. A. 6th 1909); Mueller v. Chicago \& N. W. Ry., I94 MrNo. 83, 259 N. W. 798 (I935); Hall v. St. Louis-S. F. Ry., 224 Mo. App. 43I, 28 S. W. $2 d$ 687 (1930); San Antonio \& A. P. Ry. v. Collins, 6r S. W. 2d 84 (Com. App. Tex. r933).

${ }_{22}$ Moore v. Illinois Cent. R. R., 24 F. Supp. 73 I (S. D. Miss. 1938), affd. 312 U. S. 630 (194I); 
adopt or the legislature to establish a clear and uniform basis for enforcing these agreements. ${ }^{24}$

But aside from the uncertainty and lack of understanding as to judicial enforcement of labor contracts, the factor that has probably been most responsible for the reluctance of employers and unions to seek court relief is the complete unsuitability of orthodox legal procedures. The time has surely come for the development of a legal pattern that will protect the dominant public interest inherent in responsible and bona fide collective bargaining by giving to the fruits of the process the widest recognition and protection. ${ }^{25}$

In the search for such an appropriate procedure it will be apparent, in the infrequency with which court help has been invoked by either side, that traditional judicial methods of enforcing commercial contracts are ill-adapted to the collective agreement. Court proceedings are generally costly, they are prolonged and technical, and courts are bound by statute and centuries of common law to invoke doctrines and practices developed in other fields of law or in the days of smaller business units and more personal employmint relationships. Also important is the fact that labor distrust of the judiciary, particularly of state and local courts, which originated with the indiscriminate use of the injunction and with the treatment of labor organizations as criminal conspiracies, has by no means been entirely dissipated. Another factor that cannot be overlooked is the lack of expertness in labor matters to which most judges would be the first to confess.

On an ever-increasing scale, therefore, the need for peaceful methods of settling alleged breaches of the contract and for devising and imposing appropriate and workable remedies and sanctions has been met by adoption of a system under which all such claims, not settled by negotiation according to a defined procedure, are sub-

Yazoo \& M. V. R. R. v. Sideboard, I6r Miss. 4, I33 So. 669 (1931); Gulla v. Barton, I64 App. Div. 293, I 49 N. Y. Supp. 952 (3rd Dept. 1914).

For a thoughtful analysis of these theories (usage, agency and beneficiary) see Anderson, Collective Bergaining Agreements (1936) 15 ORE. L. REv. 229; and Christenson, Legally Enforceable Interests in American Labor Union Working Agreements (1933) 9 INo. L. J. 69.

"A note in (1932) 4I YALE L. J. 1221 suggests that "the most effective legal formula capable of contemporary use in the enforcement of collective agreements would be treatment of the agreement as a valid contract between the employer and the union, creating a usage which becomes a part of all existing and subsequent individual employment contracts, unless either the employer or the employee, with actual knowledge of the agreement, voluntarily waives its benefits." Since the adoption of the Wagner Act and the decisions in J. I. Case Co. v. N. L. R. B., 32 I U. S. 332 (1944) and Order of R. R. Telegraphers v. Railway Express Agency, 32 I U. S. 342 (r944), it is very doubtful whether the employer and an employec within the bargaining unit may agrec to waive the terms of a collective agreement negotiated by the exclusive represeritative.

${ }^{25}$ In any discussion regarding the legal accountability of labor unions one cannot omit nor minimize. the deep significance of the Supreme Court's decision in Stecle v. Louisville \& N. R. R., 323 U. S. I92 (1944) and Tunstall v. Brotherhood of Locomotive Fireman, 323 U. S. 210 (1944), in which the Court upheld the right of Negro employees, not members of the union that represented their crafts, to enforce by injunction and damages the duty of the union to represent all members of the craft impartially. See Note (1945) 58 HArv. L. Rev. 448, and Freidin and Ulman, Arbitration and the National War Labor Board (r945) 58 HARv. L. REv. 309, 336-339. 
mitted to arbitration for final determination. ${ }^{20}$ It has not yet, however, been made as certain and explicit as it should be that the jurisdiction of such an arbitrator includes authority to act upon employers' claims of contract breach by the employees or the union, and authority to impose suitable penalties.

What is called for, then, is a procedure for the enforcement of labor agreements specially adapted to the collective-bargaining relationship. Every such agreement should embody, either by specific agreement of the parties or by operation of law, provisions for the resolution of claims of breach by either side. It should embody also provisions for suitable remedies and the imposition of effective sanctions by an impartial person or board, chosen preferably by the parties, but in default of their agreemènt designated by an appropriate government official, it being clearly understood that such a person, or board is to possess no authority to add to, subtract from, or modify any provision of the basic agreement. With such a procedure available for the peaceful resolution of "interpretational" disputes, no fair-minded person could then oppose a no-strike, no-lockout clause, as a term, express or legally implied, of each collective labor agreement.

Any such program designed to insure adherence to agreed-upon contract provisions would also need to consider appropriate implementations of the Wagner $\mathrm{Act}^{27}$ and possibly the Norris-LaGuardia Act. ${ }^{28}$ For there would then be little justification for continuing to extend the immunities of those statutes to employees who, in disregard of adequate peaceful procedures by which they can achieve redress for their grievances, seek to utilize self-help.

Past experience indicates that in many situations practical considerations persuade an employer, seeking to deal with breach of the agreement by individual employees acting without union support or authorization, to look in the first instance not to the courts nor to his right to discharge or suspend, but to the union to enforce discipline among its members and adherence to the contract terms. Indeed, the willingness of a union to assume this function and its capacity to carry it out constitute one of the major reasons for insuring the union's status through provisions making union membership a condition of employment. Consequently, there is sound reason for bringing the union within the orbit of accountability for claimed breaches of contract not only by itself but by its members. This result can be accomplished by enabling an employer, before he attempts himself to discipline an employee whom he asserts has breached the contract, to call on the union to do so. If the union should default in executing this responsibility the employer would then be free of the restrictions of the above-mentioned statutes in suitably disciplining the employees. In that event, too, the union as well as the employee in question might well be con-

2n Trade Agreements 1927. B. L. S. Bull. No. 468 (U. S. Dept. Labor 1928) 6; Arbitration Provisions in Union Aguecments. B. L. S. Bull. No. $7^{8}$ (U. S. Dept. of Iabor, 1944).

${ }^{27} 49$ Stat. 449 (r935), 29 U. S. C. \$150 el seq. (r940).

93 Stat. 70 (1932), 29 U. S. C. \$ror (19,40). 
sidered as having violated the contract terms-a question which, in the last analysis, would be justiciable through the arbitration machinery already described.

In connection with this question of contract enforceability the Swedish experience should also be of much interest. ${ }^{29}$ In Sweden too, prior to the adoption of legislation specifically addressed to the question, the courts had decided that trade unions and employers' organizations were responsible at law for breach of contract obligations. But this precedent, established in 1915 , was rarely used as the basis of litigation in the years that followed. Largely the same as those that have obtained here, the reasons were that the courts were notoriously slow in handling such cases and were excessively limited by traditional legal concepts. Neither the unions nor the employers were anxious to start suits which might drag out over a year or more and then yield highly unpredictable results. Prior legislative efforts in rgro and I9I6 "to promote industrial peace," both of which, be it noted, distinguished between disputes incident to the making of new agreements (these to be subject only to mediation) and "interpretational" disputes, had failed. But in 1928 the IndependentLiberal coalition government introduced and succeeded in enacting the Collective Agreement Law and the law providing for a labor court. ${ }^{30}$ Leaving the making of agreements to the parties, aided only by government mediation facilities, and leaving unaffected the strike or lockout as an essential part of the agreement-making process, the former act outlaws strikes and lockouts over disputes regarding the application or interpretation of an agreement, and sympathy strikes "if [the organization being supported] does not itself possess the right to take coercive measures," and provides that if either of the parties evades any of its contract responsibilities it may be held liable for the damage sustained by the other. ${ }^{31}$ This latter provision is the basis for the companion enactment, the labor court law, which establishes a tribunal for the exclusive purpose of dealing with "interpretational" and similar disputes, empowered to award damages, in the event of a breach, against the employer, the union, or the individual employees. The tribunal is noteworthy in three respectsits composition, its limited jurisdiction, and its flexibility in devising sanctions. Tripartite, it is composed of a chairman and two members representing the public, and four additional members, two selected from designees of the Swedish Employers' Advisory Board, and two from designees of the Federation of Trade Unions. Its jurisdiction is limited to disputes regarding the interpretation of a contract. And, probably of equal importance in the degree of success achieved, it is empowered

${ }^{20}$ Sce Pati H. Norgren, The Swedish Collective Bargaining Systrm (1941).

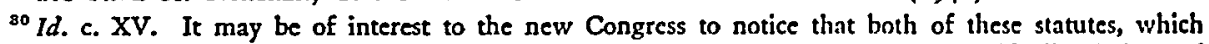
have operated with notable success, were prepared by a commission of experts, specifically designated for the purpose, after intensive study and consultation with organizations of cmployers and unions.

${ }^{8 x}$ In addition to this general provision a supplementary clause provides: "If the degree of the defendants' guilt, the injured party's connection with the origin of the dispute, the magnitude of the injury inficted or other circumstances warrant it, the amount of the damages awarded may be reduced, even to the extent of full exoneration from liability. In no case may an individual worker be required to pay damages in excess of 200 Kroner." 
to exonerate any party from guilt partially or wholly, thus being enabled to limit its decisions to the probable area within which they will be acceptable to both sides. ${ }^{32}$

Despite initial opposition by the Swedish unions, both acts have operated with a high degree of success. Union claims have run the gamut-hiring, dismissal, hours of work, classification, overtime, etc. Employer claims have been largely limited to strikes or to boycotts during the term of the agreement.

For us the significance of the Swedish experience is the combination of voluntarism in the making of agreements and legal compulsion in enforcing adherence to their terms. This is the aspect, it is submitted, that must furnish the key to a successful and acceptable labor policy in a democracy.

\section{VII}

It has been suggested that a successful government policy must embody respect for the personal and economic liberties of all citizens, employers and employees, and that it must reject compulsion in favor of voluntarism. But it is not only the government in formulating a policy whose actions must be so limited. Similar limitations must obtain with respect to the practices of employers and unions who are to operate within the policy. There is no justification, economic or social, for either discriminatory employment practices by an employer or discriminatory membership practices by a union.

Where closed shop, union shop, or maintenance of membership agreements make continued membership in the union a condition of employment, it is essential that the procedure preliminary to expulsion from the union, which would be followed automatically by discharge, meet fundamental requirements of fairness and due process, and that the causes for expulsion exclude the exercise of basic human privileges. Most union constitutions and by-laws include such safeguards. But even though the instances in which they do not are few, the injustice and the hardship may be great and, because loss of seniority is involved, irremediable. Where membership in the union is a condition of getting a job in the first place discriminatory exclusions from the union should be equally barred.

The legal right to enter into a contract that makes union membership a condition of employment is a special exception, written into the Wagner Act, to the general prohibition against discrimination on the ground of membership or non-membership in a union. But this special statutory immunity should not be enjoyed by a union which itself practices intolerance, nor should it be distorted into a vehicle for antidemocratic practices.

In the Steele and Tunstall cases, ${ }^{33}$ the Supreme Court determined that the union's right to decide questions affecting its own membership does not include the right to engage in racial discrimination. But there are other forms of equally unjustifiable

\footnotetext{
82 Two-thirds of its decisions have been unanimous. Compare figures on the tripartite National War Labor Board, with approximately $75 \%$ unanimity.

22 See note 25, supra.
} 
discriminatory reprisals. In the Portland Lumber case, ${ }^{34}$ for example, an employee had been expelled from the union for acting as a watcher for a rival union at an election ordered by the National Labor Relations Board. In the Wallace Corporation $^{35}$ and the Cliffs Dow Chemical Company cases, ${ }^{36}$ the expulsions took place because the employees had previously supported rival unions. In other cases involving questions independent of the Wagner Act employees have been expelled for criticizing union officers and committees, ${ }^{37}$ for testifying in an arbitration proceeding in favor of the company, ${ }^{38}$ for refusing to join in a strike in violation of an existing agreement, ${ }^{39}$ and for refusing to reduce their tempo of work. ${ }^{40}$

Solutions to some of these problems have been sought by the NLRB through imposing on the employer the duty to refuse to discharge an employee pursuant to the contract, notwithstanding loss of union membership, unless he is satisfied that neither the ground nor the procedure of union expulsion deprived the employee of fundamental rights. But this, it is submitted, is an incongruous way to reach an obviously desirable result. ${ }^{41}$ The result could be accomplished more directly by extending the Labor Relations Board's process to this type of discriminatory practice and by authorizing it in appropriate cases to withdraw the special statutory exception from any union whose constitution and by-laws fail to conform to minimum standards of fairness or who, in actual practice, honor such standards more in the breach than in the observance. Furthermore, the determination of such basic policy considerations is the true province of the legislature rather than of judicial or administrative bodies.

Many strong arguments have been marshalled by the unions against interference with or supervision of their internal affairs. There is undoubtedly a good deal of truth in their assertion that such efforts frequently are fronts for anti-union drives. But while it may be conceded to be generally desirable, "a union's free and autonomous control of its membership ought not to be made a fetish." 22 If the union with a closed-shop contract erects arbitrary obstacles in the way of membership or capriciously exercises its powers of expulsion and suspension, the evils of discriminatory monopoly are at once apparent.

Federal and state labor laws have expanded our concept of economic democracy

st Portland Lumber Mills, 64 N. L. R. B. 159 (1945).

${ }^{35}$ Wallace Corp. v. N. L. R. B., 323 U. S. 248 (1944).

${ }^{88}$ Cliffs Dow Chemical Co., 64 N. L. R. B. I419 (1945); see also Southwestern Portland Cement Co., 65 N. L. R. B. I (1945).

${ }^{37}$ John Wood Mfg. Co., I7 L. R. R. MAN. 267 I (1945).

${ }^{88}$ Link Belt Co., I7 L. R. R. MaN. 2775 (I946).

${ }^{30}$ Sheffield Steel Corp., 28 WAR LAB. ReP. 12 I (1945).

"Ford Motor Co., I4 L. R. R. Man. 2625 (1944).

4 The Fifth Circuit Court of Appeals has recently reversed such an order of the NLRB directed against the Aluminum Company of America. N. Y. Times, Dec. 31, r946, p. 9, col. 3 (Not yet officially reported). See also Freidin, Some New Discharge Problems Under Union Security Covenants, 1946 WIS. L. REv. 440 .

is Willcox, The Triboro Case-Mountain or Molehill? (1943) 56 HARv. L. REv. 576. 
by adding to the strength and prestige of labor unions. The steadily increasing membership of unions and their economic and political significance point to the need for procedures which promise internal democratic freedom to their members. Many of the largest and most powerful unions have on their own initiative recognized this necessity through appropriate provisions in their constitutions and by-laws. Others have not yet done so. Their occasional practices of bringing about the discharge of workers who seek to shift to another union or to exercise some other personal right operate to defeat the very freedom of choice which the labor laws, from which they derive much of their 'strength, were designed to protect.

\section{VIII}

The single essential to the success of any national policy is, in the last analysis, its broad and genuine acceptance by the people it is to affect. So it is with any policy directed toward encouraging and preserving industrial peace. Unions must be rid of the notion that they must fight continously and aggressively for their existence. This must come about not through laws but through the positive actions of management. And it seems obviously to management's and the nation's interest to put forth such efforts, for union insecurity is the manna upon which extremists feed. And unions must assume the reciprocal obligation of developing a program demonstrating their unqualified adherence to our system of private enterprise.

In the ycars immediately following adoption of the Wagner Act relatively little was realized from the collective bargaining process, principally because employers were still engaged in utilizing and abusing their concentrated strengths in an effort to prevent the growth of trade unionism and its spread to the mass-production industries. This, in turn, engendered in the unions a distrust of management as a class, many indications of which still persist. Not distrust over some single issue, but distrust generally of the bona fides of employers. Some of these practices have now been outlawed, others voluntarily abandoned. Some still remain. And to the extent that they are not abandoned they will continue to reflect an attitude which will preclude full development of the mutual trust and understanding which must furnish the base of stable and satisfactory relations.

But contemporaneous with the growth of union power since 1937 there have developed a number of union practices which have provoked in many employers, and in large segments of the public, if not a distrust of unions as a class, then an uncertainty regarding the legitimate areas of collective bargaining, union objectives, and the means adopted to secure those ends.

The likelihood of the success of a program based on the public interest in preserving voluntarism in industrial relations will be considerably enchanced if both sides are free of the resentments provoked by a perpetuation of such practices, each one of which is probably minor, but which in the aggregate constitute a source of major friction. This is not to suggest by any means that all the excesses on the one 
side have been removed. The daily news reports are proof enough of the contrary. But at least broad definition of employer responsibility has been attempted by both statute and case law. An equally deliberate effort is yet to be undertaken on the other side. The possible lines of inquiry are many. They have been suggested in a nurnber of recent articles and in proposed legislation in the consideration of which the risks of mistake and injusrice are increased by the emotions that are bound up in the subject. But the stakes are high, for we are dealing not only with economic stabiility but with the individual human rights of millions of citizens. Dispassionate and careful results are most likely to come if they are the result of agreement, or at least exploration, by such a joint body as a congressionally authorized labor-management conference with a duty to report within a fixed time to a joint congressional committee.

The ultimate aim of such a conference might well be described as the determination of standards of impropriety, the application of which would bar guilty participants from the special benefits and immunities of such laws as the Wagner and Norris-LaGuardia Acts. Such standards should be addressed both to the legitimacy of trade-union objectives and the means adopted by unions to accomplish their aims. One of the essential purposes of government is to draw distinctions between legitimate and illegitimate conduct; and this is a continuous process that must be sensitive of and responsive to changes in the social and economic mores of the times. No segment of society can insist on absolute freedom from this process of constant reappraisal. A respected contemporary philosopher has observed" that "Like science, liberalism insists on a critical examination of the content of all our beliefs, principies, or initial hypotheses and on subjecting them to a continous process of verification so that they will be progressively better founded in experience and reason."

To say; as was said at the outset of this paper, that the Wagner Act has largely succeeded in accomplishing its avowed purpose-the elimination of controversies regarding issues of organization and representation-is not to say that the Act in its present form is the perfection of legislative efforts; nor is it, obviously, to conclude that a decade of actual experience has not brought to light difficulties in its administration and new problems that it does not undertake to treat. Many of these matters have recently been the subject of careful analysis. ${ }^{44}$ Some have already been legislatively treated (the Hobbs and Lea Acts) $;^{45}$ others are embodied in proposed

is Cohen, thfi' Faith of a Liberal (1946) 8.

« See, for example, Gregory, Something Has to be Done, Fortune, Nov., 1946, 132; Note (1946) 59 Harv. L. Rev. 747.

${ }^{65} 60$ Stat. 420 (1946), 18 U. S. C. A., \$420a el seg. (Supp. 1946); 60 Stat. 89 (ig46), 47 U. S. C. A. $\$ 506$ (Supp. 1946). The Lea Act was held by a United States District Court to be unconstiturional on the ground, among others, that it undertook to deprive broadeasting station employees of rights that other employees continued to retain. U. S. v. Petrillo, 19 L. R. R. 2088 (N. D. Ill. 1946). 
law (Case Bill, Ball-Burton-Hatch Act.) ${ }^{46}$ The dangers of this bits-and-pieces approach prompt me to suggest a broad, inclusive review by labor and management representatives, culminating in a joint report to Congress. Such a review would have the great advantage of being based upon a realistic understanding of the facts of industrial life. It is not too much to hope that such realism would succeed in charting out large areas of agreement on such questions as: strikes that violate policies embodied in federal statutes or that are in breach of existing agreements; picketing that prevents entrance to and exit from the plant by supervisors not involved in the strike or others who do not choose to join it; boycotts having for their purpose not improvement in wages and working conditions, but total and unconditional exclusion from the market or the maintenance of artifical price levels; the use of abusive or false propaganda and the need for more clearly defining freedom of employers and unions to express their views during a labor dispute; and strikes or other coercive measures intended to discourage the introduction of labor-saving devices or improved techniques or materials.

These questions, involving the nature and extent of reciprocal rights and obligations of labor and management, can properly be viewed as matters for joint inquiry. The jurisdictional strike, on the other hand, directly involves only the rights and obligations of the unions, with management helpless to provide the solution although it suffers directly from the dispute. This, then, is a problem that the unions themselves must resolve or have government resolve for them.

The Wagner Act provides a procedure for the peaceful resolution of one kind of inter-union difference. When the dispute between two unions is over the question of which one has the right to act as the bargaining representative of a given group of employees-when, in other words, an employer is faced with competing claims of representation-he or either of the unions may petition the National Labor Relations Board to decide the question, and the decision is enforceable in accordance with the procedures of the Wagner Act.

With respect, however, to inter-union differences over the question of which union's members are to perform certain categories of work, no such procedure is available. The need for a mechanism to resolve this type of dispute was recognized by organized labor during the war. At the instance of the War Labor Board agreement was reached by the AFL and the CIO that jurisdictional differences of this nature, if they could not be settled by the local unions immediately involved, would be referred to the heads of the international unions or to the presidents of the AFL and CIO. If the disputes were not disposed of in that way it was agreed that they were to be submitted to final arbitration.

Peacetime finds us without any substitute machinery although the need for some such procedure is patent. If organized labor cannot itself devise a means of re-

"See Forsythe, The Settlement of Contract Negotiation Disputes: A Comparison of Proposed Legislation, supra. 
solving such conflicts without needless and costly interruptions to production, then government must assume the duty of finding a method, even though it might work in less than roo per cent of the cases. The NLRB procedure for dealing with conflicting claims of representation seems adaptable to the jurisdictional dispute over assignment of work. There might well be procedure for a formal appeal to the appropriate union heads in the event of a strike over such an issue. Upon their failure to agree upon either a substantive settlement or a procedure for settlement the government should be ready to appoint an arbitrator whose decision would be accepted at final.

Here, too, it seems entirely possible to facilitate peaceful resolution of these disputes by agreement in advance as to the standards that should normally govern the unions in reaching agreement or the arbitrator in making his award. The feasibility of advance definition of such standards is indicated by the War Labor Board's success in acting on such disputes on the basis of the principle that the right to perform various classifications of work, the question not being covered by specific contractual provision between the company and either of the unions involved, is to be governed by local area or industry practice. ${ }^{47}$

${ }^{47}$ H. K. Ferguson Co., 13 War LaB. Rep. 418 (1944); Mountain Stztes Tel. \& Ted. Co., $x_{4}$ War LAB. REP. 569 (1944).

New York City

December I, 1946 